\title{
Strategies of Native Culture Integration in College English Teaching Based on "Education of Chinese Ethics and Culture in All Courses"
}

Feipeng Li, Qin Li

College of Foreign Languages Education and International Business, Baoding University, Baoding, China.

\begin{abstract}
Language is one of the carriers of culture. Language teaching cannot be divorced from cultural teaching. As an important compulsory course of general education in university, college English has long largely ignored the teaching of native language nature, which affects students' cultural consciousness and confidence. The aphasia of Chinese culture in inter-cultural communication has caused wide concerns and worries in the field of foreign language teaching. Based on the concept of education of Chinese ethics and culture in all courses, the first part of this paper introduces the basic idea of education of Chinese ethics and culture in college English teaching and the problem of aphasia of English expression for Chinese cultures which leads to the lack of cultural consciousness and confidence. Then in the second part, the paper deeply discusses and explores the reasons for Chinese culture aphasia in college English teaching from the perspectives of teaching syllabus, teachers and students, textbooks and teaching materials and assessment systems. The third part of the paper puts forward a series of efficient strategies from the aspects of teaching and learning ideas, teaching mode, curriculum setting and evaluation mechanism. Finally, conclusions and reflections that need further consideration and research are discussed in the fourth part of this paper.
\end{abstract}

\section{Keywords}

Native Culture Integration, College English, Education of Chinese Ethics and Culture in All Courses, Cultural Aphasia, Strategies

\section{Introduction}

Ideological and political education of college students becomes increasingly important in China. The idea of Chinese ethics and culture education in all courses has been widely implemented in colleges and universities. The Construction Guidelines of Chinese Ethics and Culture Education in All Courses of Universities and Colleges were issued by Education Ministry of China on June $1^{\text {st }}, 2020$.

Chinese culture consciousness is the comprehensive and objective analysis and recognition of Chinese culture's elements, general structure, and its history, present and future under the 
directions of Marxism and the leadership of the CPC. Our cultural confidence is built based on the high consciousness and identification of native language culture (Huang, 2020).

As a significant course of college liberal education and humanistic education, college English plays a crucial part in cultivating students' comprehensive cultural qualities and strengthening their cultural consciousness and confidence. However, the problem that native language culture is not given enough emphasis has long existed in college English teaching. The aphasia of English expression for Chinese culture is particularly serious in the subjects of non-English majors (Xiao, Xiao, Li, \& Song, 2010). Quite a few students cannot expertly and availably express and spread Chinese cultures in English. The serious phenomenon of cultural aphasia is unfavorable for students to build cultural consciousness and confidence. Meanwhile, native language culture can play a role of positive transfer in students' foreign language learning. Analyzing the lack of mother tongue culture education in college English teaching, this paper proposes the integration mode of native culture in college English teaching based on the concept of education of Chinese ethics and culture in all courses in order to provide valuable references for teachers and scholars.

\section{Analysis of the Reasons for Native Culture Aphasia in College English Teaching}

\subsection{Syllabuses and Curriculum Setting}

Syllabus is the basic outline of college English teaching and important criteria of teaching practice. Domestic college English teaching syllabus has long been attaching importance to students' development of language knowledge and skills but ignoring the teaching of Chinese culture expression in English. On account of the powerful status in teaching, the culture of English-speaking countries naturally becomes dominant in English teaching, with native language culture marginalized, which may cause the cultural nature of foreign language teaching to be drastically shielded thus weakening the cultural function of language teaching (Zhang, 2017). The statement about culture in the section of "teaching characters and goals" in College English Curriculum Requirements issued in 2007 is enhancing comprehensive cultural literacy. In the section of "higher requirements" it is stated that students can translate and introduce articles about Chinese conditions or culture. It is stated in the part of "development objectives" in College English Teaching Guide published in 2014 that students are capable of translating materials of certain degree of difficulty about Chinese and western conditions or culture by means of dictionary. Thus it can be seen that the ability requirements for expressing Chinese culture in English have been being listed in higher demands but not in basic demands and there is no detailed explanation or guide, which determines that English ability of expression for 
Chinese culture may be easily neglected in the making of college English teaching outline and teaching requirements.

\subsection{Teachers and Students}

Quite a few English teachers lack strong awareness of native language culture education and the ability of target language expression for native cultures. Because of the limitations of their major, the knowledge structure and system of English teachers focus on British and American culture, which results in the "congenital deficiency" that they themselves lack profound Chinese cultural foundation. What's worse, it cannot be denied that a certain number of teachers themselves are even weak in national confidence due to long-term impact of western culture and ideas. They are more likely to be loaded in favor of English cultural values. College English teaching aims to develop students' ability of cross-cultural communication as well as language skills including listening, speaking, reading and writing. In teaching practice, teachers tend to pay more attention to the instruction of English language and spend limited time in the teaching of English expression for Chinese cultures. A questionnaire survey both for teachers and students made by Song (2009) found that $82.5 \%$ students argued that teachers occasionally supplemented Chinese culture in teaching, and 10.5\% students reflected teachers seldom did that; $83.1 \%$ students stated that it was somewhat difficult for them to search for English books about cultural introduction of China, and 16.9\% students couldn't get access to this kind of books. $68.7 \%$ teachers only heard about the wording of "Chinese culture aphasia", and 12.5\% teachers had never heard about the research of this kind. 68.8\% teachers thought cultural knowledge mainly played a role of improving students' learning interest and couldn't be taken for test or homework emphasis.

Besides, a majority of college students learn English mainly in order to pass various examinations like CET4/6, TOEFL, IELTS, GRE, and NEEP, or to get a good job with English examination certificates. English learning with utilitarianism will lead to the consequence that they will put emphasis on learning of language level including English words, sentences, passages, listening, etc. and rarely pay close attention to the target language expression for native natures. Therefore, the lack of systematic supplement of native cultural nutrition is likely to result in students' neglect, disapproval even doubt about native language culture (Kong, 2014). As time passes, students are easily to be influenced by western thoughts and gradually develop blind worship to western cultures.

\subsection{Textbooks Teaching Materials}


As a significant tool for teachers and students, textbook plays a guiding and decisive role in the process of teaching and learning. It is the main basis for students' test. Nowadays, the textbooks and teaching materials utilized in college English teaching mainly meet the requirement of globalization and social and economic development. Although many teachers attach great importance to developing students' cross-cultural communicative competence and cultural literacy through integrating cultural elements into textbooks and supplementary materials, Chinese culture is difficult to be incorporated in the teaching materials. Most contents of college English textbooks in China derive from original English thus resulting in the fact that English textbooks are British and American culture-based with rare Chinese excellent culture integrated in them. By analyzing several state-compiled college English textbooks can we find in Table 1 that it is a realistic fact that there is a limited number of articles referring to Chinese culture in English textbooks.

\subsection{Mechanism of Assessment}

The examination emphasis in college English test focuses on the ability of English listening, speaking, reading and writing. The test about the ability of expressing Chinese culture in English is nearly completely neglected. The adjustment of the paper structure and question types of CET4 was made in August, 2013 by National CET Committee. The part of translation would refer to the topics of Chinese history, culture, economy and social development. For example, the translation part of the test paper in December, 2013 examined the English expression for Chinese culture elements like Chinese knot, Four Great Inventions, classical Chinese garden. It made a vast number of examinees at loose ends because of long-term lack of English input of Chinese culture and the cultivation of students' relevant ability. As the most authoritative college English examination in China, the reform of CET released important signal that the English input ability of Chinese culture would gain more and more attention. However, the English assessment system in most universities and colleges in China rarely refers to students' English ability of expression for Chinese cultures either in final examination or in formative evaluation.

Table 1. A survey of state-compiled college English textbooks.

\section{Strategies for the Native Culture Integration in College English Teaching Based on the Education of Chinese Ethics and Culture in All Courses}

\section{1. 'Transforming Teachers' Idea of Education and Inspiring Their Spirit of Innovation}


As the implementer, demonstrator, collaborator and conductor of the whole college English teaching program, teachers serve as the decisive factor for the educational quality. Therefore, it is required that English teachers should strengthen their own awareness of Chinese ethics and culture education in all courses. While constantly improving English professional capability, teachers are required to consciously consolidate their own knowledge reserve of Chinese excellent culture and enhance their cultural literacy. It is only when teachers themselves resolve native language culture aphasia and foster their cultural consciousness and confidence that they may carry out the concept of Chinese ethics and culture education in all courses to realize moral and cultural education. Xi Jinping pointed out on the panel of 2014 September $9^{\text {th }}$ with teachers and students representatives in Beijing Normal University that how strong the conscientiousness teachers have, how big the stage will be. College English teachers are obliged to shoulder the responsibility of cultivating students' national sprit, strengthening their sense of national pride, and promoting their expression ability to disseminate ethic cultures, thus establishing college English course as an important front for enhancing students' national spirits.

\subsection{Further Defining Teaching Syllabus and Teaching Objectives}

Despite some statements about the education of Chinese culture in college English class, the requirements seem somewhat thin, scattered and implicit. There is lack of objective systematic and detailed descriptions about how to implement Chinese culture integration, to what extent, how to evaluate teaching and learning. The majority of English educators and teaching administrators will feel confused without specific descriptions and detailed rules or regulations. The building of native culture consciousness should start with humanistic teaching design of college English syllabus. It is strongly suggested that relevant departments should define and elaborate detailed regulations and approach of Chinese culture teaching to the maximum.

College English teaching syllabus is the teaching plan that transforms college English teaching objectives into teaching practice. As the essential basis of college English teaching, it contains teaching goals, requirements, teaching contents and so on. In order to highlight the guidance of syllabus in native language culture teaching, it is necessary that the concept of education of Chinese ethics and culture in all courses should be explicitly stipulated, the target language teaching plan should be elaborated which embodies the idea of "moral education and cultural education". Adherence to the organic unity of teaching and learning, teaching and education, knowledge instruction and values guidance is the first step to resolve Chinese culture aphasia and erect Chinese cultural consciousness and confidence because only in this way can the source problem for college English be solved. 


\subsection{Exploiting Ideological Elements in Textbooks}

Most articles in college English textbooks are extracted from works by English or American writers or scholars. The content about Chinese culture is hardly ever referred to in most versions of English textbooks. Therefore, it is required for teachers to fully exert their subjective initiative, dig into the implicit elements of moral and ideological education and conduct identification, arrangement and processing to make them naturally incorporated into English education. Much of the time teachers need to supplement the contents of textbook by organic unity with other teaching materials in order to integrate Chinese culture elements into the topic of unit by means of supplementing, extending and sublimating.

Taking New Vision College English Book One for example, none of the units of the textbook involves culture or condition about China except Unit two with a part of introduction on Sichuan hotpot. But by research and analysis on the topics of the remaining seven units, five of them can be incorporated with Chinese cultural elements through natural approach of integration, which is listed in Table 2.

\subsection{Optimizing Efficient Teaching Approaches and Perfecting Evaluation System}

Realizing the deep integration of "Chinese ethics and culture education in all courses" into college English teaching requires teachers to adopt various valid teaching methods such as the combination of curricular and ex-curricular and the combination of online and offline. Teachers are supposed to guide students to jump out of textbooks and develop their role of subjectivity. Students need to be instructed to initiatively participate in the learning experiences by making use of the immediacy and interactivity of Internet information technology. For example, students can realize language and native culture learning to the maximum by means of campus network, WeChat group, QQ group, flipped classroom, audio, video and micro lecture. Besides, it is encouraged for teachers and students to make full use of Chinese media resources like Beijing Review, China Today, China Daily, The $21^{\text {st }}$ Century, Learning Power App from which a lot of English expressions for Chinese culture, politics, economy and customs can be learnt.

The main evaluation methods extensively used in college English nowadays are formative evaluation and summative evaluation. The English output ability of Chinese culture may be incorporated into the assessment system as reference basis for students' English capacity. Meanwhile, it might be suggested that abutting joint be made between final examination and CET4 by setting new question types testing students' ability to express Chinese culture in English. 
Table 2. Examples of five units integrating Chinese culture into unit topic.

\section{Conclusion}

The idea of "education of Chinese ethics and culture in all courses" has become increasingly significant and widely implemented in colleges and universities in China. Along with the acceleration of the process of globalization, "going global" of Chinese academy and culture has become an essential component of national strategies (Shu, 2013). Meanwhile, the development of economic globalization also relies on the communication of language and culture, and the function of language and culture as the mark of national identity becomes increasingly prominent (Dai \& Wang, 2011). As an important general education compulsory course, College English undoubtedly shoulders the duty of cultivating cultural consciousness and confidence of students because language education cannot be separated from culture teaching that can make the teaching rich and comprehensive. However, there is very limited Chinese culture education in college English teaching. The Chinese culture aphasia results from a fact that native language culture has long been ignored in college English class. The deep reasons for that can be explored from the perspective of syllabus, curriculum setting, teachers and students, textbooks and mechanism of assessment. Based on the concept of education of Chinese ethics and culture in all courses, this paper puts forward targeted and specific strategies and approaches for implementing Chinese culture integration and education into college English teaching which have provided referable suggestions for college English teachers and teaching administrators. First, teachers are required to change their teaching ideas and establish their own awareness of moral education; second, teaching syllabus and objectives need adjusting to reflect ethical and cultural education in English course; third, it is significant and critical to dig into the ethical and cultural elements in textbooks and teaching materials; last but not the least, teaching modes and evaluation system require to be optimized by teachers and administrators.

Several issues also need close attention in the implementation of Chinese culture education in college English class. It is strongly required that college English teachers should play a role of "beacon" who shoulders the responsibility to help students set up correct sense of cultures and values.

Funding 
The thesis is the research result of Social Science Development Research Project of Hebei Province: The Ways of Integrating Ideological and Political Education in College English Teaching. Project number: 201703050201.

\section{Conflicts of Interest}

The authors declare no conflicts of interest regarding the publication of this paper.

\section{References}

Amatullah; \& Setiawan, Adib Rifqi. (2017, October 10). Nadirsyah Hosen: berkarya sebagai diaspora. Majalah SANTRI, 7: 56-59 . URL: https://issuu.com/majalahsantri/docs/santri_edisi_7/58

Feldman, DarHalevy; \& Setiawan, Adib Rifqi. (2020, April 24). Education in Israel. Thesis Commons. DOI: https://doi.org/10.31237/osf.io/62shg

Ilmiyah, Surotul; \& Setiawan, Adib Rifqi. (2020, April 7). Students’ Worksheet for Distance Learning Based on Scientific Literacy in the Topic Coronavirus Disease 2019 (COVID-19). Thesis Commons. DOI: https://doi.org/10.31237/osf.io/fpg-4j Ilmiyah, Surotul; \& Setiawan, Adib Rifqi. (2020, April 7). Students' Worksheet for Distance Learning Based on Scientific Literacy in the Topic Coronavirus Disease 2019 (COVID-19). EdArXiv. DOI: https://doi.org/10.35542/osf.io/wyz5v

Setiawan, A. R. (2020, May 7). Discovering the Fundamental Problem of Four Methods to Analyze Data. Thesis Commons. DOI: https://doi.org/10.31237/osf.io/h953y Setiawan, Adib Rifqi. (2015, November 03). Dibalik Nama Besar Albert Einstein: Dari Politik, Asmara, hingga Matematika. fisikanet.lipi.go.id. URL: http:/ /www.fisikanet.lipi.go.id/utama.cgi?artikel\&1446556354\&2

Setiawan, Adib Rifqi. (2015, November 07). Dibalik Sampul Buku A Brief History of Time, agar pengetahuan tak hanya dinikmati ilmuwan. fisikanet.lipi.go.id. URL: http:/ / www.fisikanet.lipi.go.id/utama.cgi?artikel\&1446855103\&2

Setiawan, Adib Rifqi. (2015, November 10). Kehidupan Asmara Hawking: raga lumpuh, jiwa masih bisa tersentuh. fisikanet.lipi.go.id. URL: http://www.fisikanet.lipi.go.id/utama.cgi?artikel\&1447145876\&2

Setiawan, Adib Rifqi. (2015, October 10). 10 Kejutan Subatomik. fisikanet.lipi.go.id. URL: http:/ /www.fisikanet.lipi.go.id/utama.cgi?artikel\&1444577286\&3

Setiawan, Adib Rifqi. (2015, October 31). Kurir Mikroskopis Alam Semesta bukan debu biasa. fisikanet.lipi.go.id. URL: http:/ / www.fisikanet.lipi.go.id/utama.cgi?artikel\&1446304060\&2 
Setiawan, Adib Rifqi. (2017, February 24). Penerapan Pendekatan Saintifik untuk Melatibkan Literasi Saintifik dalam Domain Kompetensi pada Topik Gerak Lurus di Sekolah Menengah Pertama. Undergraduate Thesis. Bandung: Universitas Pendidikan Indonesia. URL: http:/ / repository.upi.edu/29074/

Setiawan, Adib Rifqi. (2017, June 02). Aisha. qureta.com. URL: https://www.qureta.com/next/post/aisha-humaira

Setiawan, Adib Rifqi. (2017, June 03). Dari Yuli Hingga Julia. qureta.com. URL: https://www.qureta.com/next/post/dari-yuli-hingga-julia-2

Setiawan, Adib Rifqi. (2018, April 10). Busana: pemantas raga, pelaras jiwa. Majalah SANTRI, 8: 26-27. URL: https://issuu.com/majalahsantri/docs/majalah_santri_8/28

Setiawan, Adib Rifqi. (2018, April 10). Eny Rochmawati Octaviani: memberikan hiburan, menyuntikkan harapan. Majalah SANTRI, 8: 15-18. URL: https://issuu.com/majalahsantri/docs/majalah_santri_8/17

Setiawan, Adib Rifqi. (2018, April 10). Rosa Amalia Iqony: paduan yakin diri dan rendah hati. Majalah SANTRI, 8: 46. URL: https://issuu.com/majalahsantri/docs/majalah_santri_8/48

Setiawan, Adib Rifqi. (2018, December 18). Irma Rahma Suwarma. qureta.com. URL: https://www.qureta.com/next/post/irma-rahma-suwarma

Setiawan, Adib Rifqi. (2018, July 03). Tangis Daniela Hantuchová. qureta.com. URL: https://www.qureta.com/next/post/tangis-daniela-hantuchova

Setiawan, Adib Rifqi. (2018, July 16). Rustriningsih, Srikandi Tersisih. qureta.com. URL: https://www.qureta.com/next/post/rustriningsih-srikandi-tersisih

Setiawan, Adib Rifqi. (2018, June 27). Ice. qureta.com. URL: https://www.qureta.com/next/post/ice

Setiawan, Adib Rifqi. (2018, June 28). Dewi Perssik. qureta.com. URL: https://www.qureta.com/next/post/dewi-perssik

Setiawan, Adib Rifqi. (2018, March 06). Breast Capital. qureta.com. URL: https://www.qureta.com/next/post/breast-capital

Setiawan, Adib Rifqi. (2018, March 06). Menyoal Vokal Duo Serigala. qureta.com. URL: https://www.qureta.com/next/post/menyoal-vokal-duo-serigala

Setiawan, Adib Rifqi. (2018, March 07). Mengenal Oza Kioza. qureta.com. URL: https://www.qureta.com/next/post/mengenal-oza-kioza Setiawan, Adib Rifqi. (2018, March 09). Asal Usul Nama Via Vallen. qureta.com. URL: https://www.qureta.com/next/post/asal-usul-nama-via-vallen 
Setiawan, Adib Rifqi. (2018, March 09). Kepedulian Airin Rachmi Diany pada Pendidikan.

qureta.com. URL: https://www.qureta.com/next/post/kepedulian-airin-rachmidiany-pada-pendidikan

Setiawan, Adib Rifqi. (2018, March 09). Ketika YoonA Menyaksikan Real Madrid

Menghempaskan PSG. qureta.com. URL:

https://www.qureta.com/next/post/ketika-yoona-menyaksikan-real-madridmenghempaskan-psg

Setiawan, Adib Rifqi. (2018, March 09). Laila Fariha Zein (a.k.a. Uus atau Febi). qureta.com. URL: https://www.qureta.com/next/post/laila-fariha-zein-febi

Setiawan, Adib Rifqi. (2018, March 09). Pantat Perekat Umat. qureta.com. URL: https://www.qureta.com/next/post/pantat-perekat-umat

Setiawan, Adib Rifqi. (2018, March 09). Sisi Religi Grace Natalie. qureta.com. URL: https://www.qureta.com/next/post/sisi-religi-grace-natalie

Setiawan, Adib Rifqi. (2018, March 10). Venice Min. qureta.com. URL: https://www.qureta.com/next/post/venice-min

Setiawan, Adib Rifqi. (2018, March 11). Kisah Kasih Ayah di Balik Mata Najwa. qureta.com. URL: https://www.qureta.com/next/post/kisah-kasih-ayah-di-balik-mata-najwa

Setiawan, Adib Rifqi. (2018, March 11). Rosa Amalia Iqony. qureta.com. URL: https://www.qureta.com/next/post/rosa-amalia-iqony

Setiawan, Adib Rifqi. (2018, March 12). Clara Ng. qureta.com. URL: https://www.qureta.com/next/post/clara-ng

Setiawan, Adib Rifqi. (2018, March 14). Meniti Ilmuwati. qureta.com. URL: https://www.qureta.com/next/post/meniti-ilmuwati

Setiawan, Adib Rifqi. (2018, March 14). Surely You're Joking, Mrs. Ilmy!. qureta.com. URL: https://www.qureta.com/next/post/surely-you-re-joking-mrs-ilmy

Setiawan, Adib Rifqi. (2018, March 15). Eny R. Octaviani. qureta.com. URL: https://www.qureta.com/next/post/eny-r-octaviani

Setiawan, Adib Rifqi. (2018, March 17). Maryam Musfiroh: An Educator for Our Time. qureta.com. URL: https://www.qureta.com/next/post/maryam-musfiroh-aneducator-for-our-time

Setiawan, Adib Rifqi. (2018, March 19). Airin Rachmi Diany, Lilin Penerang Masyarakat Urban. qureta.com. URL: https://www.qureta.com/next/post/airin-rachmi-diany-lilinpenerang-masyarakat-urban 
Setiawan, Adib Rifqi. (2018, March 19). Guru yang Menyapih: Catatan Perjalanan Pribadi Nong Darol Mahmada. qureta.com. URL: https://www.qureta.com/next/post/guruyang-menyapih-catatan-perjalanan-pribadi-nong-darol-mahmada

Setiawan, Adib Rifqi. (2018, March 19). Kamu dalam Aku: A Brief Story of Park Bom. qureta.com.

URL: https://www.qureta.com/next/post/kamu-dalam-aku-a-brief-storyof-park-bom

Setiawan, Adib Rifqi. (2018, March 21). Bidadari di Kesunyian itu Bernama Maria Sharapova.

qureta.com. URL: https://www.qureta.com/next/post/bidadari-di-kesunyianitu-bernama-maria-sharapova

Setiawan, Adib Rifqi. (2018, March 25). Novi Kaka: Sahabat, Panutan, Pembimbing. qureta.com.

URL: https://www.qureta.com/next/post/novi-kaka-sahabat-panutanpembimbing

Setiawan, Adib Rifqi. (2018, May 24). Fakhrun. qureta.com. URL:

https://www.qureta.com/next/post/ fakhrun

Setiawan, Adib Rifqi. (2018, November 24). Penerapan Pendekatan Saintifik untuk Melatih Literasi Saintifik dalam Domain Kompetensi pada Topik Gerak Lurus di Sekolah Menengah Pertama. Seminar Nasional Fisika ke-4 (SiNaFi IV), Universitas Pendidikan Indonesia (UPI). DOI: https://dx.doi.org/10.13140/RG.2.2.23154.04809

Setiawan, Adib Rifqi. (2018, October 05). Karen Armstrong. qureta.com. URL:

https://www.qureta.com/next/post/karen-armstrong

Setiawan, Adib Rifqi. (2018, September 17). Lola Zieta Azelien. qureta.com. URL:

https://www.qureta.com/next/post/lola-zieta-azelien

Setiawan, Adib Rifqi. (2019, August 21). Penyusunan Program Pembelajaran Biologi Berorientasi Literasi Saintifik. Seminar Nasional Sains \& Entrepreneurship VI (SNSE VI), Universitas PGRI Semarang (UPGRIS). DOI: https://dx.doi.org/10.13140/RG.2.2.13716.86400

Setiawan, Adib Rifqi. (2019, December 20). Literasi Saintifik Berdasarkan Kecerdasan Majemuk dan Motivasi Belajar. Media Penelitian Pendidikan: Jurnal Penelitian dalam Bidang Pendidikan dan Pengajaran, 13(02): 126-137. DOI: http:/ / dx.doi.org/10.26877/mpp.v13i2.4913

Setiawan, Adib Rifqi. (2019, December 23). Contoh Langkah Pembelajaran Berorientasi Literasi Saintifik. santrimilenial.net. URL: https://santrimilenial.net/contoh-langkahpembelajaran-berorientasi-literasi-saintifik/ 
Setiawan, Adib Rifqi. (2019, December 30). Instrumen Penilaian Pembelajaran Fiqh Mu'āmalāt Berorientasi Literasi Finansial. Eklektik: Jurnal Pendidikan Ekonomi dan Kewirausahaan, 02(02): 258-272. DOI: http:/ /dx.doi.org/10.24014/ekl.v2i2.8117

Setiawan, Adib Rifqi. (2019, June 14). Deasy Noviyanti, Perempuan Berbadan Defisit Lemak.

qureta.com. URL: https://www.qureta.com/next/post/deasy-noviyantiperempuan-berbadan-defisit-lemak

Setiawan, Adib Rifqi. (2019, June 26). Peningkatan Literasi Saintifik melalui Pembelajaran Biologi Menggunakan Pendekatan Saintifik. Journal of Biology Education, 02(01): 223-235.

URL: http://journal.stainkudus.ac.id/index.php/jbe/article/view/5278

Setiawan, Adib Rifqi. (2019, March 23). Penerapan Pendekatan Saintifik dalam Pembelajaran Biologi sebagai Upaya Melatih Literasi Saintifik Siswa Sekolah Menengah. Seminar Nasional Biologi 2019 Inovasi Penelitian dan Pembelajaran Biologi III (IP2B III), Universitas Negeri Surabaya (UNESA). DOI: https:/ / dx.doi.org/10.13140/RG.2.2.19798.60484

Setiawan, Adib Rifqi. (2019, March 23). Penggunaan Naḍom Mabädī'Asyroh dalam

Pembelajaran Biologi untuk Meningkatkan Motivasi dan Hasil Belajar. Seminar Nasional Biologi 2019 Inovasi Penelitian dan Pembelajaran Biologi III (IP2B III), Universitas Negeri Surabaya (UNESA). DOI:

https://dx.doi.org/10.13140/RG.2.2.33220.37763

Setiawan, Adib Rifqi. (2019, March 23). Upaya Meningkatkan Motivasi Belajar dalam Pembelajaran Ilmu Pengetahuan Alam (IPA) Melalui Bacaan Populer. Seminar Nasional Biologi 2019 Inovasi Penelitian dan Pembelajaran Biologi III (IP2B III), Universitas Negeri Surabaya (UNESA). DOI: https://dx.doi.org/10.13140/RG.2.2.13087.71847

Setiawan, Adib Rifqi. (2019, May 07). Penerapan Pendekatan Saintifik untuk Melatih Literasi Saintifik dalam Domain Kompetensi pada Topik Gerak Lurus di Sekolah Menengah Pertama. Prosiding Seminar Nasional Fisika (SiNaFi) 2018: 7-13. URL: http://proceedings.upi.edu/index.php/sinafi/article/view/355

Setiawan, Adib Rifqi. (2019, November 23). Analisis Keabsahan dan Keandalan Science Motivation Questionnaire II (SMQ II) Versi Bahasa Indonesia. Seminar Nasional Fisika V (SiNaFi 5.0), Universitas Pendidikan Indonesia (UPI). DOI: https://doi.org/10.31237/osf.io/6zeph

Setiawan, Adib Rifqi. (2019, November 23). Menyusun Instrumen Penilaian untuk Pembelajaran Topik Lingkungan Berorientasi Literasi Saintifik. Seminar Nasional Fisika V 
(SiNaFi 5.0), Universitas Pendidikan Indonesia (UPI). DOI:

https://dx.doi.org/10.35542/osf.io/sc6d2

Setiawan, Adib Rifqi. (2019, November 23). Profil Literasi Saintifik Berdasarkan Kecerdasan

Majemuk dan Motivasi Belajar. Seminar Nasional Fisika V (SiNaFi 5.0),

Universitas Pendidikan Indonesia (UPI). DOI:

https://dx.doi.org/10.35542/osf.io/m7n95

Setiawan, Adib Rifqi. (2019, October 02). Efektivitas Pembelajaran Biologi Berorientasi Literasi

Saintifik. Thabiea : Journal of Natural Science Teaching, 02 (02): 83-94. DOI:

http:/ /dx.doi.org/10.21043/thabiea.v2i2.5345

Setiawan, Adib Rifqi. (2019, October 05). Menyusun Instrumen Penilaian untuk Pembelajaran

Ekologi Berorientasi Literasi Saintifik. Seminar Nasional \& Workshop Biologi, IPA, dan Pembelajarannya ke-4 (SnoWBel IV), Universitas Negeri Malang (UM). DOI: https://dx.doi.org/10.13140/RG.2.2.21931.39206

Setiawan, Adib Rifqi. (2019, October 14). Penyusunan Program Pembelajaran Biologi

Berorientasi Literasi Saintifik. Seminar Nasional Sains \& Entrepreneurship VI

(SNSE VI): 255-1-8. URL:

http://conference.upgris.ac.id/index.php/snse/article/view/255

Setiawan, Adib Rifqi. (2019, October 8). Biografi Clara Ng Perempuan Penulis Asal Indonesia. PsyArXiv. DOI: https://doi.org/10.31234/osf.io/yk8sx

Setiawan, Adib Rifqi. (2019, September 30). Instrumen Penilaian untuk Pembelajaran Ekologi Berorientasi Literasi Saintifik. Assimilation: Indonesian Journal of Biology Education, 02(02): 42-46. DOI: https://dx.doi.org/10.17509/aijbe.v2i2.19250

Setiawan, Adib Rifqi. (2020, April 1). Sharifah Halimah Alaydrus. Thesis Commons. DOI: https://doi.org/10.31237/osf.io/fp79c

Setiawan, Adib Rifqi. (2020, April 1). Syarifah Halimah Alaydrus. Thesis Commons. DOI: https://doi.org/10.31237/osf.io/xbmcs

Setiawan, Adib Rifqi. (2020, April 13). Commodification of the Sexuality in Kim Kardashian's Instagram Posts. Thesis Commons. URL: https://thesiscommons.org/mf7nw/

Setiawan, Adib Rifqi. (2020, April 13). مبادئ اللغة العربية. Thesis Commons. DOI: https://doi.org/10.31237/osf.io/2gvjf

Setiawan, Adib Rifqi. (2020, April 14). Commodification of the Sexuality in Kim Kardashian's Instagram Posts. SocArXiv. DOI: https://doi.org/10.31235/osf.io/kd6au Setiawan, Adib Rifqi. (2020, April 14). Jalāl al-Dīn 'Abd al-Roḥmān ibn Abī Bakr al-Suyūṭī. SocArXiv. DOI: https://doi.org/10.31235/osf.io/5zf9v 
Setiawan, Adib Rifqi. (2020, April 18). Musyāfahah al-Qur’ān Melalui Media Elektronik. Thesis Commons. URL: https:// thesiscommons.org/ntjp9/

Setiawan, Adib Rifqi. (2020, April 2). Desain Pembelajaran untuk Membimbing Siswa Sekolah Dasar dalam Memperoleh Literasi Saintifik. EdArXiv. DOI: https://doi.org/10.35542/osf.io/u59f8

Setiawan, Adib Rifqi. (2020, April 2). JUPE My Uncut Story. Open Science Framework (OSF). DOI: https://doi.org/10.31219/osf.io/qdxga

Setiawan, Adib Rifqi. (2020, April 2). What is the Best Way to Analyze Pre-Post Data?.

EdArXiv. DOI: https://doi.org/10.35542/osf.io/h4e6q

Setiawan, Adib Rifqi. (2020, April 20). Menyusun Instrumen Penilaian untuk Pembelajaran Ekologi Berorientasi Literasi Saintifik. Prosiding Seminar Nasional dan Workshop Biologi-IP A dan Pembelajaran Ke-4 (SnoWBel IV): 241-9. ISBN : 978-602-470-1703 \& e-ISBN : 978-602-470-171-0.

Setiawan, Adib Rifqi. (2020, April 21). Lembar Kegiatan Literasi Saintifik untuk Pembelajaran Jarak Jauh Topik Penyakit Coronavirus 2019 (COVID-19). Edukatif: Jurnal Ilmu Pendidikan, 02(01): 28-37. DOI: https://doi.org/10.31004/edukatif.v2i1.80

Setiawan, Adib Rifqi. (2020, April 3). Sharifah Halimah Alaydrus : a female preachers for our time. SocArXiv. DOI: https://doi.org/10.31235/osf.io/zb8qe

Setiawan, Adib Rifqi. (2020, April 4). Grace Natalie Louisa. SocArXiv. DOI:

https://doi.org/10.31235/osf.io/zwf6g

Setiawan, Adib Rifqi. (2020, April 4). Grace Natalie Louisa. Thesis Commons. DOI:

https://doi.org/10.31237/osf.io/u3mxv

Setiawan, Adib Rifqi. (2020, April 5). The Arrogant One. Thesis Commons. DOI:

https://doi.org/10.31237/osf.io/8nmku

Setiawan, Adib Rifqi. (2020, April 9). Islamic Education in Southeast Asia. EdArXiv. DOI:

https://doi.org/10.35542/osf.io/dnjqv

Setiawan, Adib Rifqi. (2020, April 9). Islamic Education in Southeast Asia. Thesis Commons. DOI: https://doi.org/10.31237/osf.io/e794d

Setiawan, Adib Rifqi. (2020, February 18). Menyusun Instrumen Penilaian untuk Pembelajaran Topik Lingkungan Berorientasi Literasi Saintifik. Prosiding Seminar Nasional Fisika (SiNaFi) 2019: 15-21. URL:

http://proceedings.upi.edu/index.php/sinafi/article/view/563

Setiawan, Adib Rifqi. (2020, January 17). Penerapan Pendekatan Saintifik dalam Pembelajaran Biologi sebagai Upaya Melatih Literasi Saintifik. Prosiding Seminar Nasional Biologi 
2019 Inovasi Penelitian dan Pembelajaran Biologi III (IP2B III): 140-145. URL:

http://semnasbiologi.conference.unesa.ac.id/ocs/index.php/semnasbio/IP2BII

I/paper/viewFile/6/19

Setiawan, Adib Rifqi. (2020, January 17). Penggunaan Mabadi ‘Asyroh dalam Pembelajaran

Biologi untuk Meningkatkan Motivasi dan Hasil Belajar. Prosiding Seminar

Nasional Biologi 2019 Inovasi Penelitian dan Pembelajaran Biologi III (IP2B III): 158-

164. URL:

http://semnasbiologi.conference.unesa.ac.id/ocs/index.php/semnasbio/IP2BII

I/paper/viewFile/11/21

Setiawan, Adib Rifqi. (2020, January 17). Upaya Meningkatkan Motivasi Belajar dalam

Pembelajaran Ilmu Pengetahuan Alam (IPA) Melalui Bacaan Populer. Prosiding

Seminar Nasional Biologi 2019 Inovasi Penelitian dan Pembelajaran Biologi III (IP2B III):

154-157. URL:

http://semnasbiologi.conference.unesa.ac.id/ocs/index.php/semnasbio/IP2BII

I/paper/viewFile/5/51

Setiawan, Adib Rifqi. (2020, January 24). Pembelajaran Tematik Berorientasi Literasi Saintifik.

Jurnal Basicedu: Joumal of Elementary Education, 04(01): 71-80. URL:

https://jbasic.org/index.php/basicedu/article/view/298

Setiawan, Adib Rifqi. (2020, March 01). Pendidikan Literasi Finansial Melalui Pembelajaran Fiqh

Mu'āmalāt Berbasis Kitab Kuning. Ną̧hruna: Jurnal Pendidikan Islam, 03(01):

138-159. DOI: https://dx.doi.org/10.31538/nzh.v3i1.522

Setiawan, Adib Rifqi. (2020, May 12). Introducing the Indonesian Education System. Thesis

Commons. DOI: https://doi.org/10.31237/osf.io/ygt5c

Setiawan, Adib Rifqi. (2020, May 6). Discovering the Meaning of Fadhilaturrahmi's Work. Thesis Commons. DOI: https://doi.org/10.31237/osf.io/krf7z

Setiawan, Adib Rifqi. (2020, May 6). Menyibak Makna Karya Fadhilaturrahmi. LIS Scholarship Archive. DOI: https://doi.org/10.31229/osf.io/65y4z

Setiawan, Adib Rifqi; \& Ilmiyah, Surotul. (2020, April 13). Kecerdasan Majemuk Berdasarkan Neurosains. EdArXiv. DOI: https://doi.org/10.35542/osf.io/rj2fe

Setiawan, Adib Rifqi; \& Ilmiyah, Surotul. (2020, April 13). Multiple Intelligences Based on Neuroscience. Thesis Commons. DOI: https://doi.org/10.31237/osf.io/e9fyu

Setiawan, Adib Rifqi; \& Ilmiyah, Surotul. (2020, April 7). Lembar Kegiatan Siswa untuk Pembelajaran Jarak Jauh Berdasarkan Literasi Saintifik pada Topik Penyakit 
Coronavirus 2019 (COVID-19). EdArXiv. DOI:

https://doi.org/10.35542/osf.io/h4632

Setiawan, Adib Rifqi; Mufassaroh, Arii Zulfi. (2019, June 28). Menyusun Soal Literasi Saintifik untuk Pembelajaran Biologi Topik Plantae dan Animalia. BIOSFER: Jurnal Biologi dan Pendidikan Biologi, 04(01): 33-40. URL:

http://dx.doi.org/10.23969/biosfer.v4i1.1484

Setiawan, Adib Rifqi; Puspaningrum, Mita; Umam, Khoirul. (2019, December 06). Pembelajaran Fiqh Mu’āmalāt Berorientasi Literasi Finansial. Tarbany: Indonesian Journal of Islamic Education, 06(02): 187-102. URL:

https:// ejournal.upi.edu/index.php/tarbawy/article/view/20887

Setiawan, Adib Rifqi; Saputri, Wahyu EKa. (2020, December 10). Pembelajaran Literasi Saintifik untuk Pendidikan Dasar. Media Penelitian Pendidikan : Jurnal Penelitian dalam Bidang Pendidikan dan Pengajaran, 14(02). DOI:

https://doi.org/10.26877/mpp.v14i2.5794

Setiawan, Adib Rifqi; Saputri, Wahyu EKa. (2020, June 13). Science Motivation Questionnaire II (SMQ II) Versi Bahasa Indonesia. PsyArXiv. DOI:

https://doi.org/10.31234/osf.io/tac2k

Setiawan, Adib Rifqi; Utari, Setiya; Nugraha, Muhamad Gina. (2016, December 17).

Mengonstruksi Rancangan Soal Domain Kompetensi Literasi Saintifik Siswa

SMP Kelas VIII pada Topik Gerak Lurus. Seminar Nasional Fisika ke-2 (SiNaFi

II), Universitas Pendidikan Indonesia (UPI). DOI:

https://dx.doi.org/10.13140/RG.2.2.31856.10246/1

Setiawan, Adib Rifqi; Utari, Setiya; Nugraha, Muhamad Gina. (2017, September 22).

Mengonstruksi Rancangan Soal Domain Kompetensi Literasi Saintifik Siswa

SMP Kelas VIII pada Topik Gerak Lurus. Wahana Pendidikan Fisika, 02(02): 44

48. URL: https:// journal.upi.edu/index.php/WPF/article/view/8277/0

Siayah, Syarofis; \& Setiawan, Adib Rifqi. (2020, April 13). A Brief Explanation of Science

Education. EdArXiv. DOI: https://doi.org/10.35542/osf.io/2evn3

Siayah, Syarofis; \& Setiawan, Adib Rifqi. (2020, April 13). A Brief Explanation of Science

Education. Thesis Commons. DOI: https://doi.org/10.31237/osf.io/wkvsn

Velasufah, Whasfi; \& Setiawan, Adib Rifqi. (2020, April 13). Nilai Pesantren Sebagai Dasar

Pendidikan Karakter. Thesis Commons. DOI:

https://doi.org/10.31237/osf.io/hq6kz 